This PDF is a selection from a published volume from the National Bureau of Economic Research

Volume Title: Controlling Crime: Strategies and Tradeoffs

Volume Author/Editor: Philip J. Cook, Jens Ludwig, and Justin McCrary

Volume Publisher: University of Chicago Press

Volume ISBN: 0-226-11512-7

Volume URL: http://www.nber.org/books/cook10-1

Conference Date: January 15-16, 2010

Publication Date: September 2011

Chapter Title: The Role of Private Action in Controlling Crime

Chapter Author: Philip J. Cook, John MacDonald

Chapter URL: http://www.nber.org/chapters/c12102

Chapter pages in book: (p. 331 - 363) 


\title{
The Role of Private Action in Controlling Crime
}

\author{
Philip J. Cook and John MacDonald
}

Private actors have a pervasive role in crime prevention and control. Here are some examples: pedestrians avoiding dark alleys at night; domestic partners moving out to end an abusive relationship; households installing burglar alarms, acquiring guns and watchdogs, and relocating to a safer community; banks, retailers, residential communities, and business improvement districts hiring security guards; credit card companies monitoring activity and suspending cards that appear to be fraudulent; individuals, households, and businesses utilizing locks, barriers, closed-circuit cameras, and electronic sensors to reduce merchandise theft.

Of course, the criminal justice system does have a considerable influence on crime, but there again private-sector actions are of vital importance. Few crimes would be solved without citizens voluntarily reporting to the police and cooperating with investigations. Given that such cooperation is costly to the private citizens and usually has no extrinsic reward, theory predicts (and the evidence supports) that this cooperation is undersupplied. The propensity of potential victims to cooperate with the criminal justice system is an attribute of criminal opportunities. Tourists and drug dealers are attractive targets for robbers, not only because of the valuables they carry, but also

Philip J. Cook is the ITT/Terry Sanford Professor of Public Policy and professor of economics and sociology at Duke University, where he is also senior associate dean for faculty and research. He is a research associate of the NBER and a codirector of the NBER Working Group on the Economics of Crime. John MacDonald is associate professor of criminology and undergraduate chair at the University of Pennsylvania.

Acknowledgments: Seunghoon Han and Maeve Gearing provided excellent research assistance. Partial support for this research was provided through a cooperative agreement from the Centers for Disease Control and Prevention (CDC) (1U49CE000773). Thanks to Jens Ludwig, Tracey Meares, and conference attendees for their suggestions on an earlier draft. The opinions expressed in this document are those of the authors only. 
because perpetrators know they are not likely to report their victimization to the police if robbed.

Given the central role of private individuals and firms in determining the effectiveness of the criminal justice system, and the quality and availability of criminal opportunities, private actions arguably deserve a more central role in the analysis of crime and crime prevention policy. ${ }^{1}$ But the leading scholarly commentaries on the crime drop during the 1990s have largely ignored the role of the private sector (Levitt 2004; Blumstein and Wallman 2000; Zimring 2007). Among the potentially relevant trends: growing reporting rates, the growing sophistication and use of alarms, monitoring equipment and locks; the considerable increase in the employment of private security guards; and the decline in the use of cash.

Criminal opportunity theory (Cook 1986) helps explain observed crime patterns and trends, and may also provide some guidance in designing costeffective crime-control policy. Private actions to protect property and avoid victimization can be encouraged or discouraged through regulation of the insurance industry and other means. Private actions to avoid, mitigate, and respond to crime tend to have substantial externalities. The resulting misallocation of resources, properly understood, may justify changes in government policy. In particular, private cooperation with the criminal justice system may be enhanced through reducing the risks and costs of cooperation, and increasing the rewards.

One creative method to harness private action to cost-effective crime control is the creation of business improvement districts (BIDs). A BID is a nonprofit organization created by neighborhood property owners to provide local public goods, including public safety. The organization has the power to tax all the owners in the district, including those who did not sign the original petition. Previous evaluations of BIDs in Los Angeles indicate that they are successful in reducing crime rates (Brooks 2008; MacDonald et al. 2009). We analyze the costs and benefits of these BIDs in what follows, including the effect on arrests and spillovers, and report a dose-response relationship for private expenditures. The rules for creating BIDs differ widely among jurisdictions, and Los Angeles appears to be a model for how to facilitate this sort of private collective action.

We conclude that the social benefits of Los Angeles BID expenditures on security are a large multiple (about twenty) of the private expenditures. We also provide an extended discussion of motor vehicle theft, where new technology appears to get much of the credit for the dramatic reductions in theft rates. These two examples, among others, illustrate our fundamental

1. The theory of how private action to prevent and avoid crime interacts with observed crime rates has been developed by Clotfelter (1978), Ehrlich (1981), Cook (1986), Shavell (1991), Philipson and Posner (1996), and others. Gary Becker's (1968) seminal article on crime and punishment includes a brief discussion of optimal private expenditures on actions to influence the probability of victimization (200 ff.). 
conclusion; namely, that that there are substantial crime-reduction benefits associated with government policies that encourage certain types of private action to prevent and control crime.

We begin by discussing the downward trend in crime during the last three decades, and the possible explanations for that trend, including increases in private security. Section 7.2, on the incentives and consequences of private prevention activities, sketches the conceptual issues and notes that private action can be either socially beneficial or harmful. Section 7.3 then considers motor vehicle theft as a case where increasingly effective private action, resulting from technical innovation and government regulation, appears particularly beneficial. Section 7.4 considers another important issue, the extent to which citizens voluntarily report crimes to the police and cooperate with the investigation. The likelihood that crimes will be reported to the police has increased over the last two decades, but there is a strong case to be made that the voluntary cooperation is undersupplied. Section 7.5 then considers the costs and benefits of business improvement districts, reporting results on the effects of BIDs in Los Angeles. Section 7.6 concludes.

\subsection{Trends in Crime and Its Prevention}

The great crime decline during the last three decades represents something of a happy mystery. We know the trend is real, rather than an artifact of the available data, since it is found in three independent sources - the FBI's Uniform Crime Reports, the National Crime Victimization Survey, and the homicide series in the Vital Statistics (Cook and Laub 2002). The causes of this decline have been the subject of much speculation. A surprising feature of this speculation is the absence of attention to the role of private actions to prevent and avoid crime.

Figure 7.1 depicts robbery and homicide rates since 1973, when the National Crime Victimization Survey (NCVS) was initiated. ${ }^{2}$ Victimization rates for robbery (and other violent crimes) varied in a narrow range until 1994, and then dropped to one-third of its 1994 level by 2004. Criminal homicide followed a remarkably similar pattern until 1999.

Property crime rates began their slide two decades earlier, and have declined rapidly since 1980 . Recent rates, as estimated by the NCVS, are just one-fifth the peak level (figure 7.2). Residential burglaries (break-ins

2. The US Department of Justice implemented a survey for measuring rates of violence and other common crime in 1973. Since then the National Crime Victimization Survey (NCVS) has contacted large samples of households (currently about 45,000) to inquire whether any members age twelve and over have become crime victims during the preceding six months, and if so to provide details. The resulting estimates tend to be substantially larger than the counts recorded by the police, and are also useful in providing the statistical basis for analyzing demographic patterns of violence - both of the victims and of the perpetrators (based on respondents' reports of their impression of the age, race, sex, and number of assailants). 


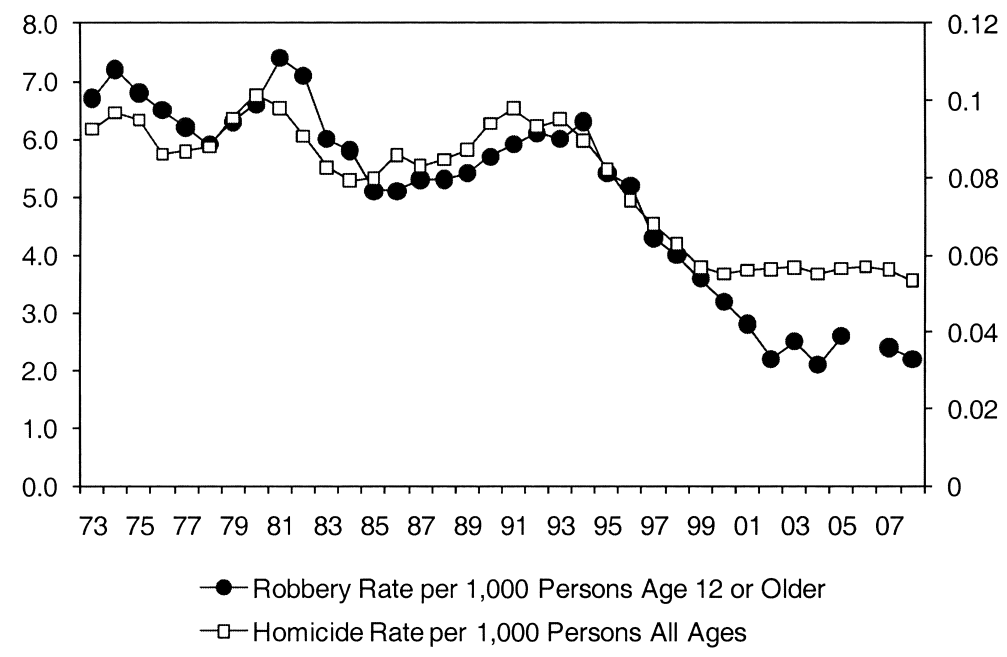

Fig. 7.1 Trend in robbery and homicide

Source: Robbery rates are from the National Crime Victimization Survey (NCVS). Criminal homicide rates are from the FBI's Uniform Crime Reports.

NCVS Property Crime Rate

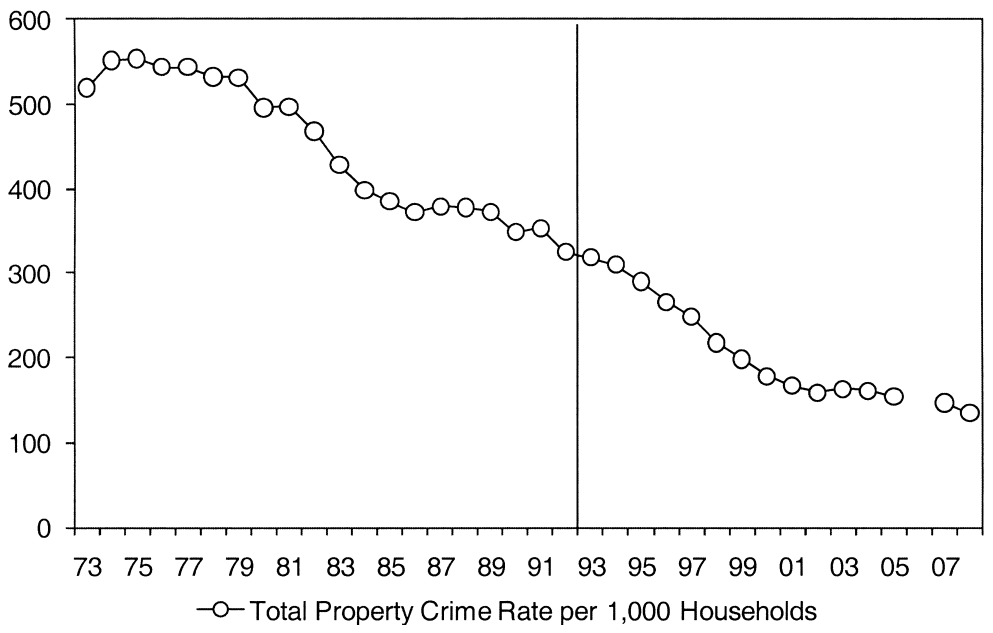

Fig. 7.2 NCVS property crime rates since 1973

Source: The National Crime Victimization Survey (NCVS) (http://bjs.ojp.usdoj.gov/content/ glance/house2.cfm).

Notes: Property crimes include burglary, theft, and motor vehicle theft. The National Crime Victimization Survey redesign was implemented in 1993. The data before 1993 are adjusted to make them comparable with data collected since the redesign. The adjustment methods are described in Criminal Victimization 1973-1995. Estimates for 1993 and beyond are based on collection year while earlier estimates are based on data year. Changes to the NCVS and their impact upon the survey's estimates in 2006 are discussed in the Criminal Victimization, 2006 Technical Notes. 
and attempts) in particular have declined 70 percent since 1976 (from 107 to 30 per 1,000 households).

The extraordinary reduction in violent crime during the 1990s has been the subject of extensive exegesis by scholars (Blumstein and Wallman 2000, 2006; Cook and Laub 2002; Zimring 2007). No expert predicted this decline, and any explanation is necessarily speculative. Levitt (2004) provides a survey of potential causes. He first notes that the decline was quite universal, affecting all demographic groups and geographic areas. With respect to urbanicity, Levitt observes that the greatest percentage improvements occurred within metropolitan statistical areas (MSAs) and especially among large cities with populations over 250,000. In fact, all of the twenty-five largest cities experienced noteworthy declines in homicide rates from their peak year (mostly in the early 1990s) to 2001, declines that ranged as high as 73 percent for New York and San Diego. Based on his analysis, Levitt ends up awarding partial credit for the crime drop to increases in the number of police, the rising prison population, the receding crack epidemic, and the legalization of abortion through Roe v. Wade. His claim for the importance of abortion liberalization is controversial to say the least (Joyce 2004), but the rest of the list is widely (though not universally) endorsed by experts. His judgment about what is not important to the crime drop includes the sustained economic growth in the 1990s, and the much-ballyhooed innovations in policing in New York and elsewhere.

A surprising feature of Levitt's analysis is the lack of discussion of private measures to prevent crime. Private crime-prevention efforts include everything from homeowners locking their doors and leaving a light on, to the employment of armed guards and armored vehicles to move large amounts of cash or valuables. The sum total of these efforts is difficult to estimate (Anderson 1999), but the private actions that can be readily measured are of the same order of magnitude as public expenditures for the criminal justice system - and they are expanding more quickly.

The Economic Census (conducted once every five years by the US Census Bureau) provides an estimate of receipts of the private security industry in 2007 as $\$ 40$ billion, as compared to $\$ 99$ billion in public expenditures on police protection in 2006. ${ }^{3}$ Estimates of the number of employees suggest something close to parity. According to Bureau of Labor Statistics' estimates of occupational employment, there were just over 800,000 police officers in 2008 , but more than one million security guards, with very similar upward trends since the mid-1980s (figure 7.3). Some of the security guards are

3. The receipts and employment for the private security industry are taken from the Economic Census for 2007, industry NAICS 5616 (excluding locksmiths). See the 2007 Census Factfinder for more information (http://factfinder.census.gov/servlet/IBQTable?_bm=y\&-geo_id=\&-ds _name $=$ EC0756I1\&__lang=en). Public expenditures on police protection in 2007 are not available yet. 


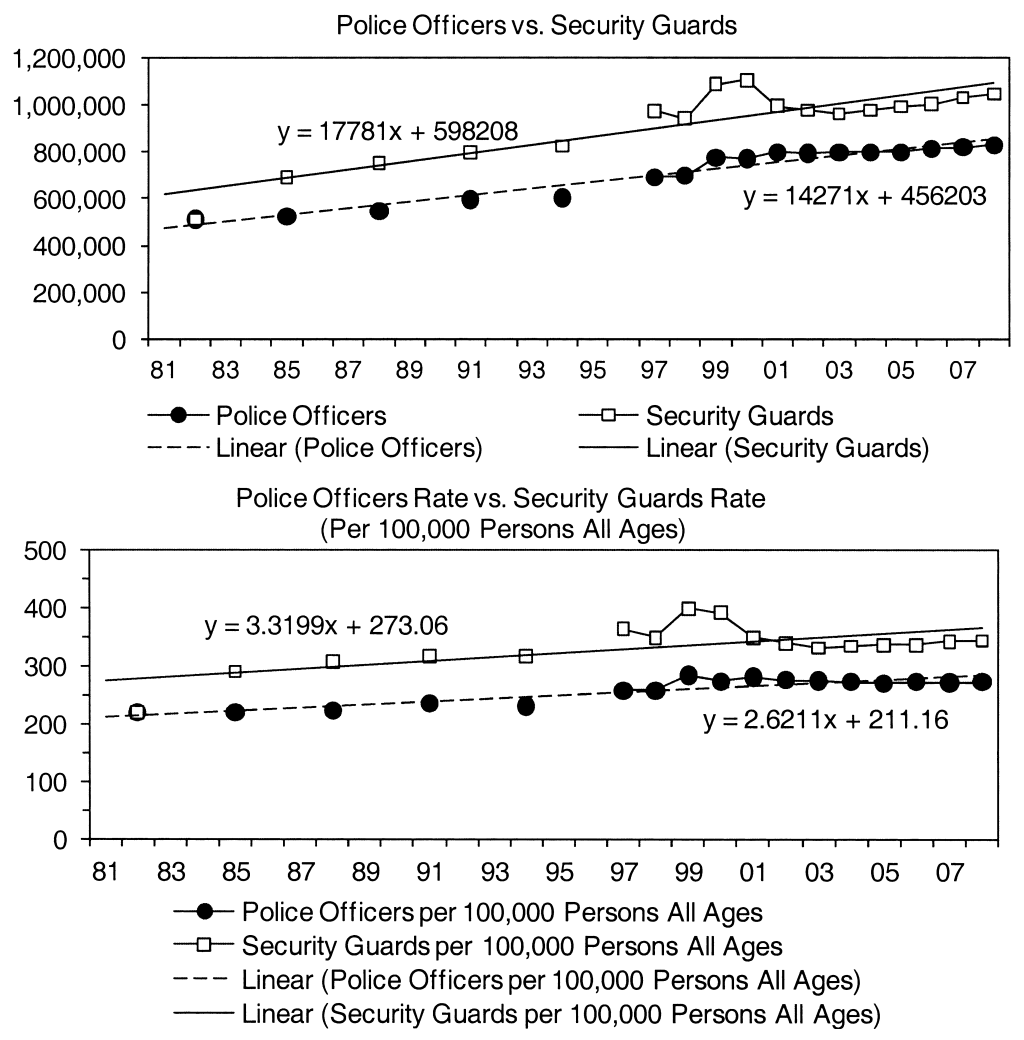

Fig. 7.3 Trends in employment of police officers and security guards, counts and rates

Sources: 1) Occupation data of Police Officers and Security Guards: Bureau of Labor Statistics, Occupational Employment and Wage Estimates, each year (1981-1995: paper version, 1997-2008: http://www.bls.gov/oes/oes_data.htm). 2) Population: Population Distribution and Population Estimates Branches, US Bureau of the Census (http://www.census.gov/popest/ national/national.html).

employed directly by the public sector; the Economic Census estimated the number of private security employees in 2007 as $820,000 .{ }^{4}$

The scope of private security and protection is suggestive of its importance in influencing crime rates, but stops short of demonstrating that importance. In what follows we discuss the conceptual issues and provide detailed discussions of theft prevention for motor vehicles, of crime reporting, and of the security expenditures by Business Improvement Districts.

4. Two other national surveys also provide estimates of the number of private security industry employees, the Current Population Survey, and the US Census Bureau's County Business Patterns. Estimates for 2007 from the three sources are in rough agreement: 820,000 (Economic Census), 780,000 (Current Population Survey), and 760,000 (County Business Patterns). 


\subsection{Incentives and Consequences of Private Prevention Activities}

Private security, and private crime-control efforts more generally, constitute an unwritten chapter in the recent literature on "what works" in crimecontrol policy. Observed crime rates and patterns reflect private choices regarding cooperation and self-protection (Clotfelter 1977; Cook 1986; Ehrlich 1996; Cornish and Clarke 2003). A systematic approach to public crime control requires understanding of the potential interactions between private and public efforts.

A place to begin the discussion of this complex topic is with the private security industry, which is ubiquitous. On any given outing, we are more likely to encounter a private security guard than a uniformed officer (Sklansky 2008, 124-25). The industry encompasses proprietary (in-house) security, guard and patrol services, alarm services, private investigations, armored car services, and security consultants, as well as security equipment (Cunningham, Strauchs, and Van Meter 1990). Private security supplements and in some cases substitutes for public action: for example, businesses in many cases investigate and resolve employee theft and fraud without ever going public. More generally, as noted by Brian Forst, "the central functions of policing - preserving domestic peace and order, preventing and responding to crimes - have always been conducted first, foremost, and predominantly by private means . . . Most crimes still are not reported to the police" (1999, 19).

Private security guards (and police officers who moonlight as private security guards) serve a narrow purpose; namely, to protect the property and people they are hired to protect. The term of art is "situational crime prevention" (Clarke 1983). The guard's job is accomplished if the robbers avoid his bank, or his corporate executive is not kidnapped, or rowdy teenagers are successfully kicked out of his shopping mall, or the would-be burglar does not enter his gated community. One partial exception is the security hired by BIDs, whose assignment is to protect an entire neighborhood.

Unfortunately there is little systematic evidence on the crime-prevention effects of private security guards (Eck 2006; Welsh and Farrington 2009). An obvious possibility is that the crime will be displaced to other, unguarded victims and places. If private security simply redistributes crime, then its public value (as opposed to private) is nil, and it creates serious equity concerns. ${ }^{5}$

While displacement is a legitimate concern, whether it occurs in practice, and to what degree, is an empirical matter. Guerette and Bowers (2009) reviewed 102 evaluations of situational crime prevention interventions, which included 574 observations. They report that displacement was about as likely as the opposite, diffusion of benefits, and that if displacement did occur, it 
tended to be less than the direct effect. Draca, Machin, and Witt (2010) report that a surge in police presence in London following terrorist attacks reduced crime in the targeted boroughs without any evidence of displacement, a null finding that is typical of evaluations of hot spots policing and related interventions.

There is also a conceptual point to be made. Lucrative opportunities, if unguarded, are likely to generate crime that would not otherwise occur. In Isaac Ehrlich's (1974) classic formulation, the supply of offenses is a function of the relative wage rates for licit and illicit activities. An increase in the net return (payoff per unit of effort) to crime will stimulate participation in criminal activity. He postulates that the payoffs to property crimes "depend, primarily, on the level of transferable assets in the community, that is, on opportunities provided by potential victims of crime" (87). But if the most lucrative "transferable assets" are well protected, then the payoff to crime is reduced. Of course, it is the most lucrative targets that tend to be most closely guarded. Banks invest more in security against robbery than, say, travel agencies. Jewelry stores display costume jewelry on open racks but keep the real thing in glass cases wired with alarms. People with meager assets do not need bodyguards to protect against being kidnapped for ransom. Credit card companies have instituted elaborate systems for preventing fraudulent use.

The social welfare implications of private action to avoid victimization depend on how well private incentives coincide with social costs. To the extent that private protection does have the effect of displacing rather than (or as well as) preventing crime, then such measures will tend to be oversupplied, since the private benefit will exceed the social benefit. That tendency may be exacerbated if the private action is subsidized by the public, as in the case of residential alarms that mobilize the police at no cost to the owner.

\subsubsection{Socially Harmful Private Precautions}

Some forms of private precautionary action may be harmful in the aggregate, even though they seem individually rational. Car alarms may be in this category, since they contribute to noise pollution in cities and have so many false positives that they have lost much of their ability to garner attention by passersby. ${ }^{6}$ Burglary alarms are also problematic: over 94 percent (and possibly as much as 99 percent) of all alarms are false, and in 2000, the police responded to 36 million false alarms at a public cost of $\$ 1.8$ billion (Blackstone, Buck, and Hakim 2005). Determining whether that cost is warranted requires comparison with the (unknown) effect on burglary rates.

Also important is the tendency of those with the financial means to avoid higher-crime communities, thus depriving those communities of resources

6. A plausible case for a ban has been argued by Friedman, Naparstek, and Taussig-Rubbo (2003). 
and social capital and contributing to a self-reinforcing process of decline. Similarly, social relations are strained in public places by private actions to avoid contact with those deemed threatening based on their appearanceyouthful minority males, for example. The private actions that have been most extensively studied are keeping and carrying a handgun for self-protection; here too there is evidence of profound harm to the community.

For some people, the ready availability of a firearm provides a sense of security against intruders, including the nightmare scenario of home invasion by violent criminals. That sense of security may be worth a great deal, whether or not it is based on a rational assessment of the chances that a handgun will be needed for this purpose, or if needed will actually be successfully deployed. Unfortunately, it is also true that handguns kept in the home are sometimes used to threaten other family members or to act on a suicidal impulse. Further, other family members, including adolescents and children, may misappropriate them and do great harm. Someone deciding whether to keep a handgun in the home thus faces a situation of competing risks - without a gun, there is a possibly greater risk of being unable to defend against a criminal intrusion, while with a gun, there are multiple risks of accident and misuse. The magnitudes of these competing risks will differ widely depending on how the handgun is stored, as well as other factorssuch as whether there are children at home, and whether household members abuse alcohol and drugs, are inclined to violence, or suffer from depression or other mental illness.

Keeping guns in the home also generates externalities for the community. Whether such externalities are positive or negative on balance is not clear a priori, but is well established by evidence. There are several logical mechanisms. A burglar may be deterred by the threat of encountering an armed householder during a break-in. On the other hand, guns have high value to burglars, and a gun-rich neighborhood, other things equal, will be a more profitable site for burglars. Guns kept in the home also become a major source to youths and criminals, with the result that the proportion of robberies and assaults involving guns increases with the density of gun ownership in urban communities. Extensive econometric and other evidence support a conclusion that private gun ownership has a net positive effect on burglary and criminal homicide rates (Cook and Ludwig 2003, 2006). The elasticity of homicide with respect to gun density is at least +0.1 . From that effect alone, the negative externality associated with keeping an additional handgun amounts to several hundred dollars per year.

Keeping a handgun for self-defense generates negative externalities, and hence is an example of an activity that is more attractive individually than collectively. There is also a reasonable concern that some private precautionary activities are undersupplied as a result of the moral hazard created by insurance and even by the criminal justice system. Motor vehicle theft provides an illuminating case study of these possibilities. 


\subsection{Motor Vehicle Theft and Criminal Opportunity}

The stakes in the prevention of auto theft are high. About one in eight property crimes reported to the police in the United States are thefts of motor vehicles. (This figure does not include thefts from vehicles, which is a still higher number.) Of the $\$ 17$ billion lost by victims of property crime in 2003, over half was the result of auto theft (FBI 2004). ${ }^{7}$ The prevention of auto theft has been an active concern of government since the introduction of state registration systems in the 1920s and 1930s.

In recent decades, technological development in electronics and information processing have created increasingly sophisticated locks, alarms, video surveillance systems, and tracking devices, which arguably have taken much of the profit out of motor vehicle theft. (They are also important in the prevention of such diverse crimes as shoplifting, robbery, and credit card fraud.) Figure 7.4 depicts the sharp downward trend in motor vehicle theft rates in recent years, as evident in both NCVS and Uniform Crime Reports (UCR) data. The absolute number of thefts reported to the police in 2008 is lower than the count in 1989, when there were half as many vehicles on the road. It is entirely plausible that the sharp declines are due in part to tracking systems and "target hardening" locks - that is, to investments in private prevention. A spokesman for Highway Loss Data Institute opined that "It's a much tougher job to be a car thief today" (Leinwand, 2009).

From the potential motor-vehicle thief's perspective, the opportunities created by unoccupied vehicles differ widely in terms of their "quality," which can be defined by the dimensions that guide purposeful choice: the effort and skill required to succeed in the theft, the payoff if successful, the likelihood of arrest, and the legal and private consequences if arrested. Each of these dimensions is arguably affected by private crime-prevention efforts.

\subsubsection{Types of Prevention}

Prevention efforts by the owner/driver can be sorted into three clusters: (a) care exercised when deciding where to park and whether to lock up; (b) investment in locking devices that make it more difficult to enter the car (when locked) and to drive off; and (c) investment in devices that make it easier to track a stolen vehicle and identify it as such, including LoJack and OnStar. ${ }^{8}$ There is a public stake in the decisions made by private actors in each of these cases; theft imposes costs on the public as well as the owner

7. Keep in mind, however, that auto theft is more likely to be reported than other types of property crime, and hence is disproportionately represented in the Uniform Crime Reports.

8. Using the Ehrlich-Becker (1972) dichotomy, the first two clusters are primarily selfprotection, since they reduce the chance of victimization (both theft of vehicle and theft from the vehicle), while the third is primarily self-insurance, since it reduces the expected loss by increasing the chances of recovery if the vehicle is stolen. In their analysis, the third is unambiguously a substitute for insurance. 
Motor Vehicle Theft Rate: UCR vs. NCVS (Per 100,000 Persons All Ages)

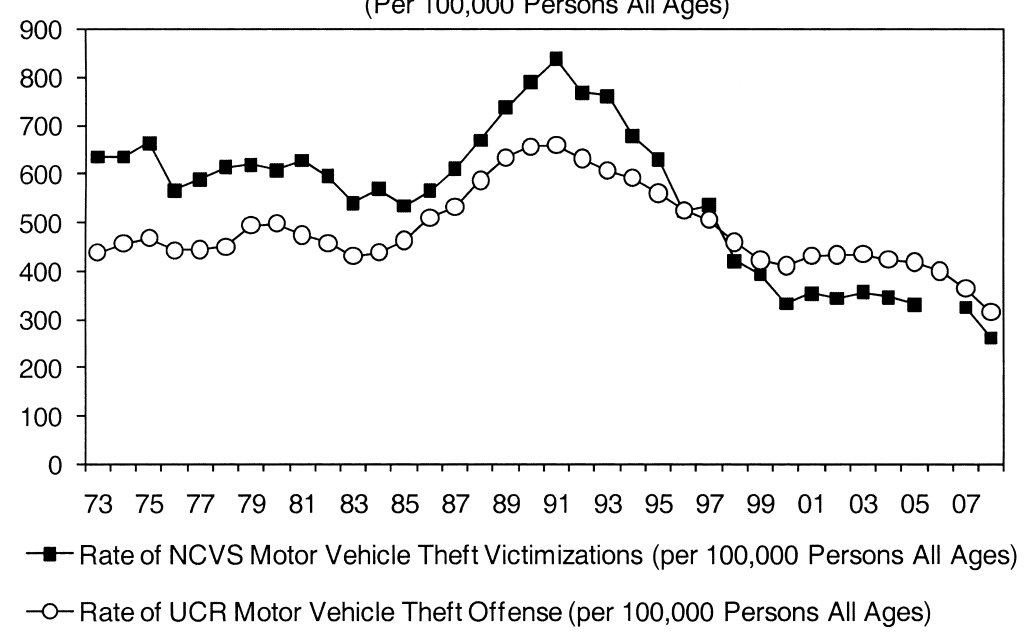

\section{Fig. 7.4 UCR and NCVS trends on motor vehicle theft}

Sources: 1) UCR MVT: 1973-2007 data from Crime trends, BJS homepage (http://bjs.ojp .usdoj.gov/dataonline/Search/Crime/State/RunCrimeTrendsInOneVar.cfm); 2008 data from Crime in the United States (http://www.fbi.gov/ucr/ucr.htm). 2) NCVS MVT: Criminal Victimization in the US, various years. 3) Population: Population Distribution and Population Estimates Branches, US Bureau of the Census (http://www.census.gov/popest/national/national .html).

and his insurance company. Furthermore, since the private incentives do not match up well with social costs, there is the usual justification for government intervention.

To develop these points, consider an individual who is deciding whether to park her vehicle overnight in a secure parking structure or in a dark alley. Parking in the alley raises the probability that the car will be stolen. If she carries comprehensive insurance she will only bear a fraction of the immediate loss. If the car ends up being stolen and the police are notified, which they almost always are, then the subsequent investigation and possible recovery, arrest, court processing, and sanction will all be conducted primarily at public expense. (While the police could choose not to respond to the theft report, that inaction would ensure a failure to arrest, which would dilute the general deterrent and possibly increase the auto-theft rate.) Thus the cost of theft to the owner is less than to the public, creating a moral hazard to be negligent about parking the car-both because of insurance, and also because of the chance that the police will probably recover the car. For that reason we expect that there will be more vehicles parked in alleys than is socially optimal.

But that conclusion presumes that the overall auto-theft rate is influenced by her decision of where to park. If the auto theft rate is not influenced by the density of accessible vehicles, but only by the supply of thieves, then her 
decision would be of little or no public concern. Indeed, under the assumption that the theft rate is independent of the density of attractive opportunities, her parking in the alley would reduce the likelihood that another car was stolen, conveying a positive externality on other owners without imposing any net cost on the police or public. If private prevention actions displace crime without reducing it, then the result will be excessive prevention (Clotfelter 1978; Shavell 1991). There will be too few vehicles parked in the alley.

In reality, there is good reason to expect that displacement will not be complete. If motor-vehicle thieves are heterogeneous with respect to skill and motivation, then private precautions would likely affect the overall rate of auto theft. For example, since some potential thieves are unskilled opportunists (i.e., "joyriders"), then a general increase in driver precaution in this regard will reduce theft rates by making an encounter with a suitable target less likely. Indeed, there is evidence that improved locking devices on motor vehicles have had a disproportionate effect on joyriders, relegating them to stealing cars that are parked with the key left in the ignition (Tremblay, Clermont, and Cusson 1994; Copes and Cherbonneau 2006). One indicator is that the percentage of arrests for auto theft involving juveniles has declined from 44 percent in 1994 to 25 percent in $2006 .{ }^{9}$

For professional thieves, who steal to order for a chop shop or illegal exporter, the value of the vehicle matters. If owners of the most valuable vehicles tend to take the most effective precautions against theft, then while theft displacement to older and cheaper models will occur, the precautions are not without consequence for the theft rate, since they tend to reduce the overall profitability of professional auto theft.

Unfortunately there is not much empirical evidence on this matter. One analysis by the UK Home Office assessed the effect of steering column locks, providing some evidence that they reduced theft rates (Webb 1994). Germany was the first nation to mandate such locks; in 1961 all motor vehicles were required to have them, even if it required retrofitting. The sharp drop in theft rates that followed is likely due in part to the large effect on joyriding (Clarke and Harris 1992). US auto makers began incorporating steering column locks in 1969 as a result of a federal mandate, but only on new vehicles. The effect on overall theft rates, if any, would logically have been gradual, and is not readily isolated from other trends (Webb 1994).

Most vehicles are now equipped with an ignition immobilizer, an electronic device that blocks the engine from starting unless the key with the correct microchip is present. Immobilizers have been mandatory in all new cars sold in the United Kingdom (since 1998), Australia, and Canada. In

9. The percentage of arrests (of those under eighteen) for other property crimes also declined during this period, but not by as much: for example, the arrest percentage for larceny declined from 33 percent to 25 percent. http://www.ojjdp.ncjrs.gov/ojstatbb/ezaucr/asp/ucr _display.asp. 
the United States 86 percent of new cars are built with the device, compared with fewer than 5 percent in 1989 (Leinwand 2009). We know of no scholarly evaluation of these devices, but the Insurance Bureau of Canada states on their website: "After extensive research, IBC determined that electronic engine immobilizers are the most effective means of automobile theft deterrence." microchip, or carjack the vehicle, or haul it away-or steal an older vehicle from a dwindling and aging stock.

\subsubsection{Private Actions to Aid Police Investigation}

The third cluster of private actions to prevent motor vehicle theft are those intended to track the vehicle and facilitate recovery, arrest, and successful prosecution. The original device was simply the Vehicle Identification Number (VIN) that, when affixed to the vehicle and registered with a public agency could be used to identify stolen vehicles. Manufacturers began using public VINs in the mid-1960s in response to the Highway Safety Act of 1966. In 1984 Congress adopted legislation that resulted in a requirement that manufacturers of designated high theft passenger car lines inscribe the VIN onto the engine, the transmission, and twelve major body parts. The goal was to deter professional thieves who steal cars for their parts. An analysis by the National Highway Traffic Safety Administration (NHTSA 1998 ) found that parts marking cost just $\$ 4.92$ per vehicle, and that a 2 percent reduction in the theft rate would create consumer benefits exceeding that cost. The analysis found that the implementation of the standard was accompanied by a marked shift in theft rates from new (marked) vehicles to older (unmarked) vehicles; this effect was as large as 20 percent when cars were new, but it weakened as they became older (NHTSA 1998).

The only device that has been subjected to a thorough cost-benefit analysis is LoJack (Ayres and Levitt 1998). LoJack is installed at the dealership for a onetime cost to the owner of $\$ 695$. It consists of a small FM radio transponder that can be hidden in one of twenty different places, and is switched on after the police have been notified of a theft. It then sends a silent signal to local police vehicles equipped with LoJack vehicle tracking units. It claims a 90 percent recovery rate, compared with a 63 percent chance of recovery of a typical car without Lojack. ${ }^{11}$ More important from a social benefit perspective is that it serves as a powerful deterrent to car theft; Ayres and Levitt (1998) found that each dollar spent on LoJack resulted in a reduction in the costs of auto theft of about $\$ 10$. The substantial reduction in the rate of auto theft associated with the introduction of LoJack into a city, even with market penetration amounting to a few percentage points, appears to result

10. http://www.ibc.ca/en/Insurance_Crime/Prevention_Investigation/Immobilizers/ Immobilizer-FAQs.asp

11. Joanne Helperin (2009). See also Ayres and Nalebuff (2005). 
from its ability to assist law enforcement in making arrests of professional thieves and chop-shop owners - individuals who may be very active in this market and not otherwise likely to be arrested. A thief who steals 100 cars per year is almost sure to steal at least one LoJack-equipped vehicle even if only 2 or 3 percent of all vehicles are so equipped - because the thief has no indication of whether any particular vehicle is equipped. Interestingly, LoJack enhances the deterrent effect by prohibiting any visible indication that LoJack has been installed. ${ }^{12}$

While LoJack provides owners with some reduction in expected theft loss, the main beneficiaries of an individual's decision to acquire LoJack are the public at large - and the insurance companies, if rates for comprehensive insurance do not adjust to reduced payouts. Ayres and Levitt estimate that the positive externality of one LoJack device is over $\$ 1,300$ annually. Though this value is somewhat less in cities with relatively low rates of auto theft, it appears that it would be in the public interest for additional regions to license LoJack and for individuals to be subsidized or otherwise encouraged to install it. In a few states, most notably Massachusetts, insurance companies are required to provide a discount on premiums for comprehensive insurance, and some companies provide such a discount voluntarily. But the company that insures an individual who installs LoJack only enjoys a fraction of the benefit (in proportion to their market share) and is unlikely to pass on anything like the full social value to the premium holder.

LoJack is not the only vehicle recovery system. Some manufacturers offer factory-installed systems. Most prominent is GM's OnStar, which combines a GPS transmitter and cellular technology and has a number of features that provide private benefits lacking for LoJack - for example, automatic emergency notification of a crash, and the ability to locate the vehicle when someone else (a thief, or a teenage son) is driving it. The GPS technology requires an unobstructed line of site to satellites, and so will not help locate the vehicle when it is parked in a building. But it does provide an increased chance of tracking and recovery, with a greater private payoff.

\subsubsection{Conclusions}

The case of auto theft is of interest both because it dominates statistics on property loss due to theft, and because it has been an active area of private innovation. But there are similar issues with the prevention of burglary, shoplifting, credit card fraud, and other property crimes.

In reviewing the three clusters, we are left with several conclusions. First,

12. Gonzalez-Navarro (2008) analyzes the results of a program in Mexico where some Ford models in some states were equipped with LoJack at company expense. The result was to cut theft rates for those models by over half, without displacement to other models. But there was geographic displacement - states not included in the LoJack experiment experienced an increase in theft for the included models. 
new technology has been incorporated in locking devices to the point where the amateur thieves of old (the joyriders) are limited to opportunities created by exceptional carelessness or a dwindling number of older cars. Even the professionals find it difficult to start and drive away the new models. This target-hardening trend is broad enough to suggest that it deserves partial credit for the dramatic reduction in auto theft rates since the early 1990s. Second, private prevention actions may displace theft to other vehicles, but the extent of displacement depends on the circumstances. If adoption of effective locking technology is broad enough, the scope for displacement, at least within the realm of auto theft, is limited. Third, the most effective device for preventing theft appears to be LoJack, which works as a general deterrent by increasing the likelihood that professional thieves and chop shop owners will be arrested and punished. This is a classic case of publicprivate coproduction of prevention, where motor vehicle owners invest in a device that provides exceptionally useful information to police investigations.

The public has a stake in reducing auto theft; a general reduction in the risk of victimization is a local public good. For LoJack, and perhaps some other devices, the owner's payoff to adopting is far less than the social value. This misalignment of private and public payoffs can be dealt with by government regulation of manufacturers, public subsidies, or insurance. Only nine states have regulations requiring insurers to provide car owners with discounts for comprehensive insurance for antitheft devices. The amount of the discount differs but is typically 15 to 20 percent for passive devices that are automatically activated when the vehicle is locked. Massachusetts leads the way with a minimum 25 percent discount if they have both an antitheft device and an auto recovery system like LoJack. ${ }^{13}$ The fact that most states do not have such insurance regulations is more likely the result of political failure than of objective differences in costs and benefits.

Most difficult, perhaps, is to regulate carelessness. It is entirely possible that there is excess carelessness given the moral hazards created by insurance and the fact that the police do not charge for recovering a vehicle. If it is less costly at the margin to reduce theft by reducing private carelessness than to increase public enforcement, we could institute penalties for, say, leaving a car unlocked in a public place with the key in the ignition, or allowing insurance companies to refuse to pay off if such a vehicle is stolen, or charging the owner for the police resources devoted to tracking down the vehicle. Such measures may pass a cost-benefit test, but are not likely to be popular with the public.

13. Insurance Information Institute, "Auto Theft" (December 2009), http://www.iii.org/ IU/Auto-Theft/. Blackbox GPS lists insurance companies that offer discounts: http://www .tessco.com/yts/partner/manufacturer_list/vendors/deluo_gps/pdf/Insurance-Discounts.pdf. 


\subsection{Private Cooperation with the Criminal Justice System}

While improved locking devices no doubt deserve some credit for the decline in auto theft, the evidence in support of effectiveness is much stronger for LoJack. As we discussed, the mechanism by which LoJack achieves its remarkable results is by providing law enforcement with timely information on the location of the stolen vehicle, and thus greatly enhancing the likelihood of successfully arresting and putting out of business the professional thieves and chop shop operators. LoJack is an example of effective coproduction of crime prevention from a combination of private inputs (the LoJack transmitter) and public inputs (the police investigation). There is nothing unusual about public-private coproduction in law enforcement (Clotfelter 1993). In fact, for the criminal justice system to prevent property and violent crimes requires private cooperation throughout the enforcement process (Gottfredson and Gottfredson 1988; Kruttschnitt and CarboneLopez 2009).

The first step in this coproduction process is that a private citizenusually the victim - notifies the police of a crime. (The typical process for detecting consensual transactions of illicit drugs, vice, or corruption is quite different, since such crimes usually become known to the law enforcement only through police investigation.) Since reporting a crime is in most circumstances a public service provided at some private cost and little benefit, it is not surprising that a majority of crimes of theft and violence are never made known to the police. Among the exceptions are criminal homicide and auto theft, the latter because the police are usually able to recover a vehicle if they know it has been stolen, and because insurance companies will not pay off if the police have not been notified.

\subsubsection{Recent Trends}

During the last two decades reporting rates for property and violent crimes have trended upward. Figure 7.5 documents this trend since 1973 for four crimes: noncommercial robbery, aggravated assault, residential burglary, and auto theft. For each type of crime we offer two indicators. The first is from the NCVS, and is based on the respondent's statement of whether a criminal victimization was made known to the police. Since that measure may be biased (the respondent may be reluctant to admit that she did not report a crime), we also offer a second indicator, the ratio of "crimes known to the police" from the UCR, to the NCVS estimate of the number of such crimes. ${ }^{14}$ For all four crimes we observe that both indicators have an upward trend. The trend lines in the figure are broken between 1992 and 1993 to

14. The "crimes known" variable is reported by the FBI's Uniform Crime Reports based on administrative data submitted by local police departments. For robbery and burglary, the UCR count is adjusted to exclude crimes against businesses and organizations, since such crimes are excluded from the NCVS sampling frame. 


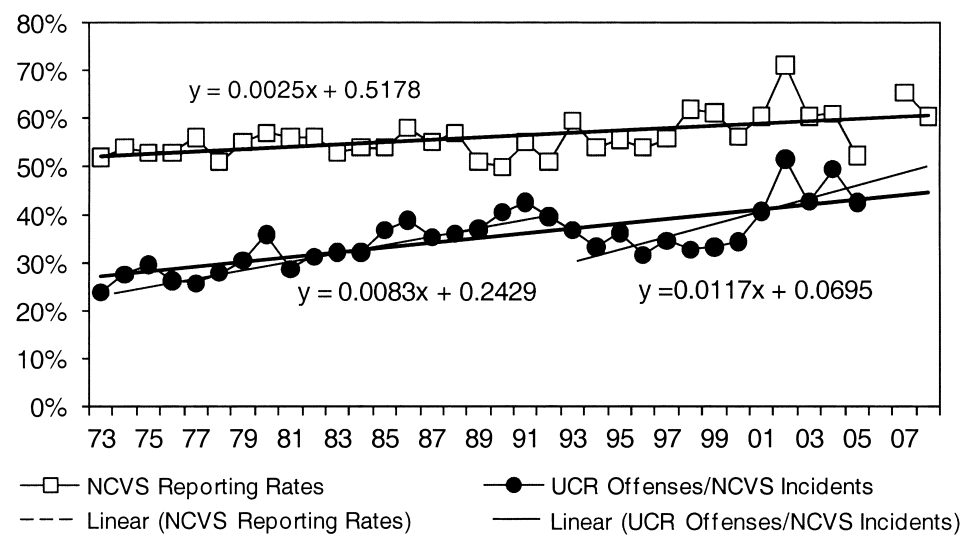

B

Reporting Rates, Aggravated Assault

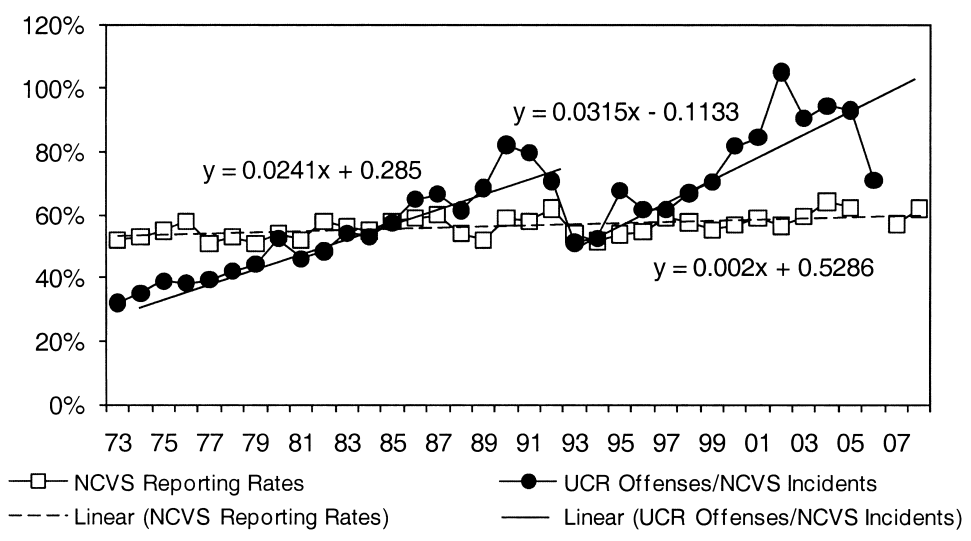

C

Reporting Rates, Residential Burglary

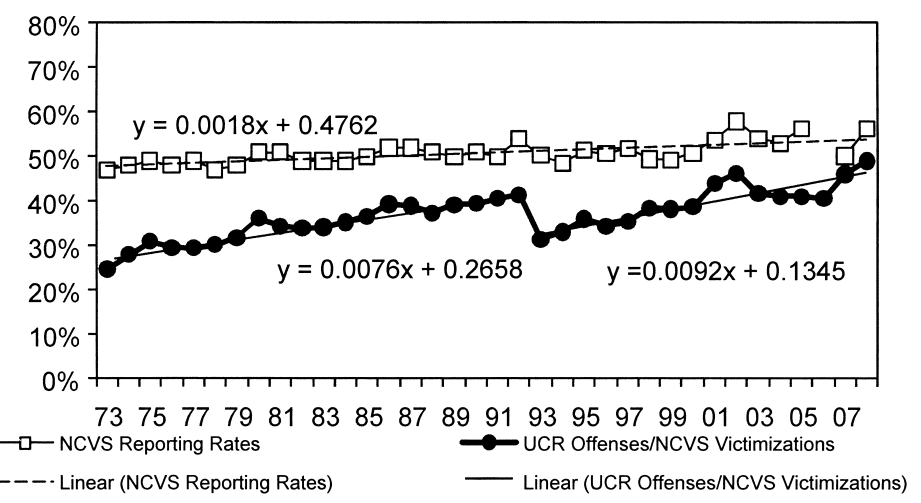

Fig. 7.5 Crime reporting rates: $A$, robbery; $B$, aggravated assault; $C$, burglary; and $D$, motor vehicle theft 
D

Reporting Rates, Motor Vehicle Theft

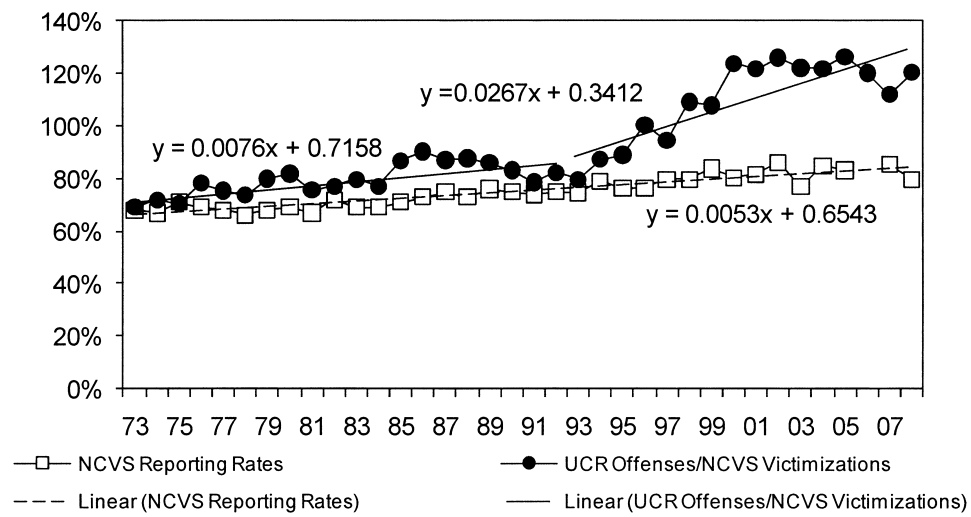

Fig. 7.5 (continued)

reflect the redesign of the NCVS, which had the effect of increasing the estimates for some types of crime (Kindermann, Lynch, and Cantor 1997).

As expected, the NCVS self-report measure (with its potential bias) exceeds the UCR/NCVS measure for robbery and burglary. Strangely, however, that is not the case for aggravated assault or auto theft. Indeed, for auto theft the UCR/NCVS measure goes as high as 120 percent. If the NCVS estimate of the volume of auto theft is accurate, then a ratio above 100 suggests that a substantial fraction of reports to the police are false. A benign possibility is that sometimes owners report a vehicle stolen when really it has been misplaced. The malign possibility is a fraudulent attempt to collect insurance money on a vehicle that may only exist on paper, or for which the actual value is less than the insured value. In any event, the fact that the NCVS item on reporting also indicates an upward trend suggests that the upward trend does not result just (or only) from an increase in false reports.

Since making a crime known to law enforcement is the first step in the process by which the criminal justice system sanctions crime, it is plausible that the upward trends account for a portion of the crime drop during this period. But neither the reasons for these trends nor their consequences have been systematically analyzed. What we do know, thanks to a careful study by Eric Baumer and Janet Lauritsen (2010), is that the upward trend in the NCVS reporting rates is not the result of trends in the mix of crime; they find that a strong upward trend in the NCVS measure persists after controlling for victim-offender relationship, socioeconomic characteristics of the victim, injury, weapon type, and demographic characteristics of the victims and offenders. ${ }^{15}$

15. Baumer and Lauritsen (2010) conclude that reporting rates (based on NCVS items) followed an upward trend since 1978 for aggravated assault, sexual offenses, burglary, motor vehicle theft, and larceny. They find a primarily downward trend for robbery, which contradicts our finding. They did not consider our alternative measure, the UCR/NCVS ratio. 
In what follows we consider the incentives for cooperating with the system as a way to identify potential policy levers for sustaining this trend, whatever its cause in the past.

\subsubsection{Incentives for Cooperation}

Under some circumstances it is in the self-interest of the victim to report a crime. Reporting may be required by insurance companies, or may be warranted just from the prospect of recovering stolen property. There may also be a financial incentive for a victim to report a violent crime if he is eligible for payments under a state victim compensation program (which mandates that the victim cooperate), or has hope that the offender, if caught and convicted, may be required to pay restitution as part of a settlement or sentence. In unusual cases there is a possibility of a remunerative tort case against the offender, which would be facilitated by a criminal prosecution. Retail businesses may routinely report shoplifting and other crimes in the hope of acquiring a reputation that will have deterrent value.

The decision to report is not always or even predominantly based on a financial calculation. A sense of public duty, or desire for revenge, may play a role. Related findings are that victims are more likely to report if they believe that the police will be able to do something about the crime, and if the crime is serious (Reiss 1971; Levitt 1998; Baumer and Lauritsen 2010). (A downward trend in crime could therefore increase reporting because residents perceive that police are more effective, and because they actually are, given their lighter workload.) Officials are required to report certain crimes that become known to them-some states require serious offenses occurring in schools to be reported, and medical providers are required to report gunshot wounds and suspected child abuse. Victims may report domestic violence in the hope that the violent partner will learn a lesson and desist.

On the other side of the ledger are the private costs of reporting and cooperating with an investigation. In most cases it is just a matter of taking the time to give a report, but sometimes there is reason to fear more serious consequences. Many victims may wish to avoid contact with authorities because of their immigration status or their own illicit activities - which is what makes undocumented aliens and prostitutes so vulnerable to predators. Of course there is a reasonable fear of retaliation, especially when dealing with criminal gangs or acquaintances. There may also be a general distrust or disaffection of the police, coupled with a "no snitching" norm in the neighborhood.

Given this list of considerations on both sides of the ledger, there are a variety of possible explanations for the upward trend in reporting. There are potentially positive effects of technology - the introduction of mobile phones (which reduce the cost of reporting) and of improvements in 911 systems - and of concerted efforts to improve the relationship between police and public through community policing with its neighborhood watch and related community-participation programs, and efforts to improve the per- 
ception of the fairness and legitimacy of policing (Tyler and Fagan 2008; Skogan and Frydl 2004). "Consistent with this claim, survey data reveal that the percentage of citizens who rate the police highly in terms of honesty and ethical behavior has risen from about $37 \%$ in the mid-to-late 1970 s to about $61 \%$ by the middle of the present decade" (Baumer and Lauritsen 2010, 137). Whether the private incentive to cooperate with the criminal justice system has grown over this period is an intriguing possibility.

\subsubsection{Policies to Improve Cooperation}

In recent years conditional cash transfers have been touted as a potentially effective ingredient for a variety of social programs that are intended to change private behavior (Corby et al. 2000). The possibility of paying for information that would be helpful to law enforcement is not a new one-for example, the national nonprofit organization CrimeStoppers got its start in 1976. Community chapters of CrimeStoppers collect private contributions and use the funds to pay rewards (up to $\$ 1,000$ ) for anonymous information leading to arrest. Other "tip" programs have been set up by police departments, focusing on particular problems such as illegal gun possession. In a sense it is difficult to see how such programs could not be cost-effective (assuming they are well managed), since a tip that is key to arresting a perpetrator of serious crime is presumably worth far more than $\$ 1,000$ - but we are not aware of any systematic evaluations.

More generally, victims who cooperate with law enforcement have been treated better over the years, starting with the victims' rights movement during the 1970s. President Reagan appointed a task force that offered over sixty action recommendations that "encouraged the expansion of victim services and suggested practices to make the criminal justice process and related victim service delivery system more "victim friendly" (Tobolowsky 2001, 9). The report helped inspire state and federal legislation. "Currently, the federal government and all of the states have statutory victim compensation programs and restitution provisions which authorize restitution as a probation condition or as an independent sentence, or both. A victim right to restitution is also included in several of the state constitutions" (11). Since 1984, the federal government has provided states with grants to support victim compensation and victim services.

It seems reasonable to suppose that the promise of victim compensation and restitution would motivate victims to report to the police and cooperate with the investigation and trial. But in practice restitution is usually not required as part of a felony sentence in state courts: in 2006, 18 percent of violent-crime defendants and 27 percent of property-crime defendants were required to pay restitution. ${ }^{16}$ Even when it is part of the sentence, there is no guarantee that it will be collected and transferred to the victim. 
Victim compensation programs also tend to offer less than meets the eye, although they do play a role. The first such program was created in California in 1965, and spread rapidly (with a federal assist in the 1980s). They have been operating in every state since at least the 1990s. In these programs the government is typically payer of last resort, and only for certain expenses incurred in violent crimes: medical expenses not otherwise covered, some lost wages, funeral expenses. They have garnered little public notice. In FY 2009, California reported about 200,000 serious violent crimes and received 54,572 applications for compensation, paying out $\$ 94$ million, or about $\$ 1,700$ per claim (http://www.boc.ca.gov/docs/stats/ CountyCompApps.pdf). We know of no evaluations of victim programs from the point of view of whether and how much they induce reporting and cooperation.

\subsection{An Evaluation of Business Improvement Districts in Los Angeles}

Business improvement districts offer an interesting example of private action that combines situational crime prevention with a close working relationship with the police, and which, while nongovernmental, are the result of collective action. These self-taxing entities raise money to pay for private security guards, combat disorder, and generally to repair "broken windows" directly, while also advocating for improved policing and other city services (MacDonald and Stokes 2006). Services provided by BID organizations within a defined district are typically supplemental to those provided by public agencies. The BID services often include trash collection, private security officers, and closed-circuit television (CCTV) cameras, as well as marketing and place promotion, and development planning. The BIDs exist in urban areas "to make places attractive - safer, cleaner, and more marketable" (Mitchell 2008, 3).

Business improvement districts emerged out of legal institutions that have been used by urban municipalities in America since the early 1800s to finance improvements in local infrastructure like sidewalks, street lighting, and sewers that directly benefit adjacent property owners. Briffault $(1999,415)$ notes that the public benefit "justifies public action to provide the improvement; the private benefit justifies requiring landowners to defray a portion of the municipality's expenses." The BID model is a form of special-purpose district that has the power to assess local landowners and is consistent with common-use service arrangements (Houstoun 1997).

The BIDs are private entities but they are typically chartered by state legislation and regulated by local governments (Mitchell 2001). The method for collecting assessments for BIDs differs across jurisdictions. In some states the assessments are collected by municipal agencies and then transferred to a private sector nonprofit organization that manages the operations of the BID. In other locales assessments are collected by the nonprofit orga- 
nizations managing the BIDs. Relying on nonprofit agencies to collect assessments can create difficulties when property owners are delinquent in paying. Frankford Special Services District in Philadelphia, for example, reported collecting only $\$ 39,000$ of its mandated $\$ 85,000$ assessment in 1997, and the city had to make up for the budget shortfall through federal community development block grants (Stokes 2006). Not surprisingly, some businesses and property owners resent being asked "to make an additional payment to finance services they think should be paid for out of their existing tax dollars" (Briffault 1999, 385). Despite differences in state-enabling legislation and methods of administration, the popularity of BIDs is evident from their growth in US cities. In 1999 there was an estimated 404 BIDs in the United States (Mitchell 2001). The International Downtown Association estimates there are over 800 BIDs in the United States in 2009.

In Los Angeles (LA), California, BIDs are managed and operated by private nonprofit organizations, but they are chartered and regulated by the city government. The LA city clerk's Administrative Services Division manages the city's BID program. The city levies an assessment on the BID's behalf through property or business tax collection, charges each BID a fee for the transaction, and then transfers the funds to the nonprofit organization managing the daily operations of each BID (MacDonald et al. 2009).

The adoption of a BID in LA requires extensive planning and support from business and property owners. A formal planning phase for the BID must be outlined and presented to the LA city clerk's office. In the planning phase LA requires the use of outside consultants to develop a formal BID plan including a membership database, the design and geography to incorporate the BID, an assessment formula for financing services, and a plan to incorporate a nonprofit organization to manage daily operations of the BID. At least 15 percent of the business owners or more than 50 percent of the property owners must sign supporting petitions for a formal BID proposal to be accepted by the city. Subsequent to a formal proposal being approved by the LA city clerk's and city attorney's office a laborious process of legal and legislative oversight ensues, including: a formal vote of the majority of property owners and merchants weighted by level of property assessment; a five-year service and budget plan for operating the BID; and a review of documents by the LA city clerk's and city attorney's office. After all planning stages have been successfully met, a series of public meetings are held prior to an enabling vote by the LA city council that officially charters BIDs (City of Los Angeles Office of the City Clerk; MacDonald et al. 2009). After five years, the BID has to be reauthorized by another formal plan and vote of property owners to continue its operations. Los Angeles offers some financial assistance for BID formation planning (City of Los Angeles Office of the City Clerk).

Los Angeles has also embedded several accountability measures to regulating BIDs. For example, the nonprofit organizations managing BIDs are 
required to provide the city with financial reports, and the city can audit and shut down any BID organization whose operations are deemed to be out of compliance with the proposed service plan, or for financial irregularities (City of Los Angeles Office of the City Clerk; MacDonald et al. 2009).

Many of the BIDs in LA focus their services on sanitation and private security of common public-space area enhancements to the existing publiclyfunded sanitation and police services. "Clean" and "safe" are common terms used by BIDs in LA. Eleven of the thirty BIDs operating in LA in 2005 spent more than $\$ 200,000$ a year on private security operations, with nearly equal amounts being spent on sanitation services. The Figueroa Corridor BID and Hollywood Entertainment BID provide good examples of BIDs with a focus on sanitation and safety. The Figueroa Corridor BID was formed in 1998 by business property owners in direct response to economic decline and a concern with area crime. From the outset, its efforts were focused on improving community safety by employing uniformed private security workers (Safety Ambassadors) who patrol the district on foot, bike, and evening vehicle patrols and assist in keeping order. It spends close to $\$ 500,000$ a year, or almost half of its operational budget, on these officers. This BID also employs cleaning crews that remove trash, debris, and graffiti (Holter 2002). On a monthly basis the BID collects and removes more than 3,000 to 4,000 bags of trash and 1,000 to 5,000 square feet of graffiti. ${ }^{17}$

The Hollywood Entertainment BID employs armed private security officers who are retired law-enforcement officers. These officers patrol the Hollywood district seven days a week during evening hours, initiate citizen arrests when they observe violations of the law, and work closely with the LAPD. It spends just over $\$ 1$ million a year on private security, or approximately 47 percent of its operating budget. It has also installed eight CCTV cameras at intersections in the district for use by the LAPD (http://www .hollywoodbid.org/).

Brooks (2008) conducted an evaluation of the effects of BIDs on changes in crime in LA neighborhoods and found that their adoption was associated with a significant drop in the number of serious crimes reported to the police between 1990 and 2002. Her analysis of BID effects on crime controlled for time-stable differences between neighborhoods, and used as a control group BID neighborhoods that proposed BIDs but did not end up adopting them. A more recent analysis by MacDonald and colleagues (2009) using data from 1994 to 2005 in LA found significant pre-post declines in robbery and violent crimes in areas that adopted BIDs.

These evaluations did not fully consider the cost of BIDs to the public, and in particular the use of police services. The BID provides greater capacity to mobilize the police, and BIDs have been criticized for encouraging the increased use of police arrest powers in their districts and displacing 
disorder and crime to adjacent areas (Harcourt 2005). If BIDs reduce crime by increasing arrests in their districts, the additional cost to the public of arrests, related prosecutions, and incarcerations should be incorporated in the cost-benefit analysis.

We examined the effect of BIDs on crime and arrests in LA, applying quasi-experimental statistical methods to fine-grained annual crime data for the years 1994 to 2005 . We used the year of BID implementation to reflect the exposure to the BID intervention and examine the pre-post changes in the incidence of crime and arrests in affected neighborhoods, controlling for overall time trends. Our innovations, with respect to the existing literature, included an analysis of the impact on arrests, an analysis of spillover effects, and an estimate of the dose-response relationship with an associated costbenefit analysis. A detailed report of methods and results is presented in our recent paper (Cook and MacDonald, forthcoming).

The results from our analyses indicate a substantial effect of BIDs on crimes and arrests. The introduction of BIDs is associated with roughly twenty-eight fewer total serious crimes per neighborhood. Interpreting this estimate from the sample mean of 249 crime incidents per BID neighborhood suggests an 11 percent relative decline in crime associated with BID implementation. In terms of crime motivated by environmental opportunities the results appear to be particularly strong. The largest marginal shift in crime occurs for robberies, followed by burglary and auto theft. For example, interpreting the estimate of robberies from the sample mean of twenty-seven incidents per BID neighborhood suggests an 18 percent reduction associated with BIDs.

Additionally, BID introduction is not associated with increased use of arrest powers by the police. On the contrary, across all models BIDs are associated with significantly fewer police arrests over time. The introduction of BIDs is associated with an average BID neighborhood reduction in 9.62 arrest incidents, reflecting a 32 percent decline. Importantly, these models we estimated controlled for crime and arrest trends in adjacent reporting districts through the inclusion of police division*year interaction terms. The substantive results for BID effects are also the same across all crime and arrest outcomes when we control for the two years leading up to and after BID adoption.

These results we just discussed treat BIDs as binary, either present or not. In fact, they are highly heterogeneous with respect to resources devoted to crime prevention. We used as a measure of private security dosage the expenditure per reporting district. The results, shown in table 7.1, are consistent with those for BID presence, but specifically indicate that BIDs with greater private security expenditures per neighborhood (denoted Security\$) have greater reductions in crime and arrests. (Note that these regressions include an indicator for BIDs that did not spend on security.) We conclude that an additional $\$ 10,000$ per neighborhood spent by BIDs on private security 
Effect of BID private security spending on crimes and arrests

\begin{tabular}{lccccc}
\hline & \multicolumn{5}{c}{ Regression estimates } \\
\cline { 2 - 6 } & Total & Robbery & Assault & Burglary & Auto theft \\
\hline Crime & & & & & \\
Security $\$$ & $-3.371^{\mathrm{a}}$ & $-0.590^{\mathrm{a}}$ & $-0.431^{\mathrm{b}}$ & $-0.533^{\mathrm{a}}$ & 0.166 \\
$(\$ 10,000)$ & $(2.89)$ & $(3.98)$ & $(2.01)$ & $(2.87)$ & $(0.64)$ \\
ZeroSecurity $\$$ & -5.66 & $-3.80^{\mathrm{a}}$ & -0.354 & -1.320 & 0.223 \\
$(0-1$ variable $)$ & $(0.50)$ & $(2.78)$ & $(0.16)$ & $(0.63)$ & $(0.07)$ \\
Arrest & & & & & \\
Security\$ & $-1.658^{\mathrm{a}}$ & $-0.505^{\mathrm{a}}$ & $-0.558^{\mathrm{a}}$ & $-0.199^{\mathrm{a}}$ & $-0.205^{\mathrm{a}}$ \\
$(\$ 10,000)$ & $(3.28)$ & $(5.06)$ & $(3.02)$ & $(3.48)$ & $(2.65)$ \\
ZeroSecurity\$ & -0.907 & -1.515 & -4.049 & -0.746 & -0.151 \\
$(0-1$ variable $)$ & $(0.11)$ & $(1.92)$ & $(0.90)$ & $(0.90)$ & $(0.29)$ \\
\hline
\end{tabular}

Notes: Each column reports estimates from two regressions, first with a crime count as the dependent variable (top half) and then for an arrest count (bottom half). $t$-values reported in parentheses. Coefficients are multiplied by 10,000 for Security\$. All regressions include neighborhood and division*year fixed effects. Standard errors were adjusted for larger variances within higher crime neighborhoods. $N=12,864$ (1,072 reporting districts*12 years).

${ }^{\mathrm{a}} p<.01$

${ }^{\mathrm{b}} p \leq .05$

reduces the average number of crimes per neighborhood by 3.37. Separate regressions by crime type indicate that an additional $\$ 10,000$ per neighborhood reduces robbery, assault, and burglary counts by about 0.5 incidents. The only exception to this pattern is auto theft, which has no discernible association with BID spending on private security. The BID expenditures on private security also appear to be associated with a decreased use of arrest powers by the police. Across all models a greater amount of BID spending on private security per neighborhood is associated with significantly fewer police arrests. An additional $\$ 10,000$ of spending per neighborhood by BIDs is associated with 1.65 fewer arrests. Crime-specific results indicate that most of the reduction in crime is for robbery and assault.

An additional expenditure of $\$ 10,000$ per neighborhood (reporting district) would represent a 19.3 percent increase above the average amount spent $(\$ 51,906)$ for the twenty-one BIDs that provide private security to their neighborhoods. The Hollywood Entertainment and Downtown Industrial BIDs have the highest dosage of private security expenditures per neighborhood at $\$ 190,120$ and $\$ 194,712$, respectively.

What effect do BIDs have on neighboring, non-BID areas? It is possible that BID effects may be confined to their neighborhoods and have no impact on their closest neighbors. Alternatively, BIDs may displace crime to their neighboring areas as their districts become less attractive for criminal opportunities. The BIDs could also generate spillover effects and reduce crime for their adjacent neighbors by enhancing the overall level of crime preven- 
tion in their districts and making even their next-door neighborhoods less attractive to criminals. In any event, when we tested for spillovers directly, we found no evidence of either positive or negative effects.

\subsubsection{Effects of BIDs on Crime-Related Social Costs}

Next, we consider direct crime and criminal justice cost savings resulting from BID investments in area-specific services. As we have seen, adoption of BIDs reduced the average number of crimes and arrests in affected neighborhoods. How much are these reduction worth? The social costs of crime victimization include direct costs related to medical and mental health services, productivity losses (wages, housework, etc.), and pain and suffering. Two methods have been used to monetize the consequences of crime. Most common has been to infer crime costs from jury awards for torts that have the elements of crimes like robbery or assault. This ex-post compensatory approach has most recently been pursued by Roman (2009). In principle the more valid approach is to estimate the willingness-to-pay (WTP) for a reduced probability of victimization, which provides an ex-ante assessment that should include the costs of crime avoidance and concerns about family and friends as well as self. Ludwig and Cook (2001) utilized a contingentvaluation survey to estimate willingness to pay for a reduction in gun violence, and Cohen et al. (2004) applied this method to estimating the value of reducing several other types of crime. Estimates utilizing both approaches are reported in table 7.2. ${ }^{18}$ Note that the unit social cost of a robbery is quite similar in the two methods, but that the jury-award method produces a higher estimate for assault. Jury awards and WTP show that an additional spending of $\$ 10,000$ per neighborhood by BIDs yields a social-cost savings of $\$ 149,362$ to $\$ 155,242$ for robberies and $\$ 34,217$ to $\$ 52,812$ for assaults. ${ }^{19}$ The conclusion is clear in either case - even if we just limit the assessment to robbery and assault, the social benefit of crime reduction is a large multiple (about twenty) of private expenditure.

This conclusion is strengthened when the savings from reduced arrest rates are included. The average cost of an arrest and related prosecution in LA (in 2005 dollars) has been previously documented by investigators at the RAND Corporation (see Turner, et al. 2007). An average arrest by the LAPD was estimated to cost $\$ 473$, which includes the cost of officers at the crime scene and police station booking an offender (four hours total at $\$ 34.90$ per hour), the cost of case review by a detective (one-and-a-half hours at $\$ 42.82$ per hour), a citation package delivered to the LA district attorney (one hour at

18. The average direct victim injury cost is much lower and estimated to be $\$ 30,690$ per robbery and \$23,212 per assault (Miller, Cohen, and Rossman 1993). These cost estimates are conservative because they exclude a number of external social costs including how crime influences decisions about travel, housing, business locations, prices of insurance, the value that individuals place on avoiding victimization, and other factors.

19. A separate estimate using direct injury costs per crime from Miller, Cohen, and Rossman (1993) indicates that an additional $\$ 10,000$ in BID spending on private security is associated with $\$ 18,199$ social injury-costs savings for robberies and $\$ 10,027$ for assaults averted. 
Cost savings from BIDs for crimes and arrests per neighborhood

\begin{tabular}{lcc}
\hline Incident costs & Per $\$ 10,000$ private security & $95 \%$ conf. interval \\
\hline $\begin{array}{l}\text { Robbery } \\
(\$ 263,122)^{\mathrm{a}}\end{array}$ & $\$ 155,242$ & $\$ 78,011-\$ 232,473$ \\
$\begin{array}{l}\text { Assault } \\
(\$ 79,390)^{\mathrm{a}}\end{array}$ & $\$ 34,217$ & $\$ 511-\$ 67,923$ \\
$\begin{array}{l}\text { Robbery } \\
(\$ 253,156)^{\mathrm{b}}\end{array}$ & $\$ 149,362$ & $\$ 75,056-\$ 223,668$ \\
$\begin{array}{l}\text { Assault } \\
(\$ 122,249)^{\mathrm{b}}\end{array}$ & $\$ 52,689$ & $\$ 786-\$ 104,592$ \\
$\begin{array}{l}\text { Arrest } \\
(\$ 2,947)^{\mathrm{c}}\end{array}$ & $\$ 4,863$ & $\$ 1,963-\$ 7,798$ \\
\hline
\end{tabular}

Note: Estimates of costs/crime taken from the publications and converted into 2005 dollars.

${ }^{a}$ Estimate taken from Cohen et al. (2004).

bEstimate taken from Roman (2009).

'Estimate taken from Turner et al. (2007).

$\$ 34.90$ per hour), and a booking fee of $\$ 25$. The total cost of each court appearance related to an arrest was estimated to be approximately $\$ 2,474$. Court costs included the costs associated with the district attorney's prosecution, the public defender representation, and the costs of a case appearing in court. The average costs of an arrest and court prosecution is estimated at $\$ 2,947$. These criminal justice cost estimates are conservative because they exclude the average cost of jail, future prison, and potential lost wages due to incarceration.

Taking the estimated average reduction 1.65 arrests per additional $\$ 10,000$ BID expenditures on private security per neighborhood and multiplying that by the average costs of an arrest and court prosecution $(\$ 2,947)$ translates into an approximate savings of $\$ 4,863$. This suggests that there is a substantial benefit to the public in reduced criminal justice expenditures for money spent by BIDs on private security, with no indication that these benefits are offset by arrests going up in neighboring locations.

The bottom line is that the local security provided by BIDs in Los Angeles reduces crime and the number of people who are arrested and processed in the criminal justice system. These effects provide a social benefit that is a multiple of the private expenditure. While we do not have estimates of the effects of BID security on the profitability of the constituent businesses, the popularity of BIDs suggests that the participants are satisfied. In effect, BIDs may well increase the profitability of doing business in the central city.

\subsection{Conclusion}

Criminal justice policy is mostly concerned with how best to use public resources to reduce crime by reducing the population of active criminals through deterrence, incapacitation, and rehabilitation of criminals. That 
formulation of the policy problem tends to downplay the role of private action. In fact, the volume and distribution of crime is not solely determined by the population of active criminals. Individuals choose whether to commit crime, and what crimes to commit, based in part on the characteristics of available opportunities. Those criminal opportunities are created primarily by private action. Expressed differently, private individuals and firms produce private security, providing the first line of defense in reducing the supply of tangible opportunities for crime, and to some extent making crime less attractive and profitable. If policymakers ignore the fundamental role of private action, they are in danger of misunderstanding observed trends and patterns in crime - and of failing to recognize effective tactics for reducing the costs of crime.

It is also true that the productivity of the criminal justice system depends crucially on private inputs. A successful investigation leading to arrest and conviction of a criminal usually requires private citizens to voluntarily provide the necessary information, beginning with the crime report. Since private cooperation tends to be costly to the provider and have little tangible payoff, it is likely to be undersupplied - the public benefit of cooperation is greater than the private benefit. In the coproduction process by which the private and public sectors serve to influence the crime rate, greater public effort to enhance private inputs is a promising avenue to efficient crime control.

While there is a good prima facie case for positive marginal social benefit of private inputs into the criminal-justice process, the case is less clear for the provision of private security. We have argued that some privatesecurity actions have negative externalities, such as keeping a handgun for self-defense and thereby providing a lure to burglars and an enhanced supply of guns to criminals. Likewise, normal precautions in protecting property may cause displacement to other targets. So there can be no general claim that there is too little private security. The effects must be assessed on a caseby-case basis. For example, it is entirely plausible that the near-universal adoption of sophisticated locking devices for motor vehicles gets part of the credit for greatly reduced rates of auto theft (whereas car alarms have little effect and substantial social cost). The dissemination of steering-column locks and immobilizers has been encouraged by government regulation of auto manufacture and of rate setting in comprehensive insurance, and more could be done along these lines. A similar analysis could be applied to other types of property crime.

More important is the challenge of finding cost-beneficial policies to increase private inputs to the criminal justice process. There are a number of policy instruments available. Tangible costs and benefits can be enhanced through monetary rewards, expansions in victim compensation and restitution, and respectful treatment of citizens who do come forward. Overcoming distrust of the police and "no snitching" norms (with the implied threat of retaliation) may be more difficult, but is surely important. For whatever 
reasons, we have seen steady increases in crime reporting over the last three decades. (The growing trust in police may get part of the credit.) The quality of private inputs may also be improving, due to technological change. The most carefully studied example is LoJack, which provides police investigators with the exact location of the stolen car. The advent of cell phones may also have increased the provision of timely reports to the police.

Security guards, most of whom are privately employed, surely play a role in improving cooperation with the police. The number of security guards exceeds the number of police, and the two sorts of employment have grown apace. Of particular interest is the formation of business improvement districts that focus much of their efforts on controlling crime in public spaces around commercial districts. By hiring private security and working closely with the police, BIDs coproduce crime control - a local public good. We have demonstrated that BIDs reduce crime, and that the reduction in crime is coupled with reductions in arrest rates. The BIDs in Los Angeles clearly pass a cost-benefit test. Indeed, the social cost savings from BID security expenditures is an order of magnitude greater than expenditures, just as is true for Lojack. If BIDs as successful as LA's are to emerge elsewhere, one key is to provide the legal framework that facilitates the formation and funding of BIDs.

\section{References}

Anderson, David A. 1999. "The Aggregate Burden of Crime." Journal of Law and Economics 42 (2): 611-42.

Ayres, Ian, and Steven D. Levitt. 1998. "Measuring Positive Externalities from Unobservable Victim Precautions: An Empirical Analysis of Lojack." Quarterly Journal of Economics 113 (1): 43-77.

Ayres, Ian, and Barry Nalebuff. 2005. “Stop thief!” Forbes, January 10.

Baumer, Eric P., and Janet L. Lauritsen. 2010. "Reporting Crime to the Police, 19732005: A Multivariate Analysis of Long-term Trends in the National Crime Survey (NCS) and National Crime Victimization Survey (NCVS)." Criminology 48 (1): 131-85.

Bayley, David, and Clifford Shearing. 2001. "The New Structure of Policing: Description, Conceptualization, and Research Agenda." Research Report. Washington, DC: National Institute of Justice.

Becker, Gary S. 1968. "Crime and Punishment: An Economic Approach.” Journal of Political Economy 76 (2): 169-217.

Blackstone, Erwin A., Andrew J. Buck, and Simon Hakim. 2005. "Evaluation of Alternative Policies to Combat False Emergency Calls." Evaluation and Program Planning 28 (2): 233-42.

Blumstein, Alfred, and Joel Wallman. 2000. The Crime Drop in America. New York: Cambridge University Press. 2006. "The Crime Drop and Beyond." Annual Review of Law and Social Science 2:125-46. 
Briffault, Richard. 1999. "A Government for Our Time? Business Improvement Districts and Urban Governance." Columbia Law Review 99 (2): 365-477.

Brooks, Leah. 2008. "Volunteering to Be Taxed: Business Improvement Districts and the Extra-Governmental Provision of Public Safety" Journal of Public Economics 92 (1-2): 388-406.

City of Los Angeles Office of the City Clerk. Undated. Business Improvement Districts. Accessed January 7, 2010. http://cityclerk.lacity.org/bids/.

Clarke, Ronald V. 1983. "Situational Crime Prevention: Its Theoretical Basis and Practical Scope." In Crime and Justice: An Annual Review of Research, volume 4, edited by Michael Tonry and Norval Morris, 225-56. Chicago: University of Chicago Press.

Clarke, Ronald V., and Patricia M. Harris. 1992. "Auto Theft and its Prevention." Crime and Justice 16 (1): 1-54.

Clotfelter, Charles T. 1977. "Public Services, Private Substitutes, and the Demand for Protection against Crime." American Economic Review 67 (5): 867-77.

- 1978. "Private Security and the Public Safety." Journal of Urban Economics 5 (3): $388-402$.

. 1993. "The Private Life of Public Economics." Southern Economic Journal 59 (4): 579-96.

Cohen, Mark A., Roland Rust, Sara Steen, and Simon Tidd. 2004. "Willingnessto-Pay for Crime Control Programs." Criminology 42 (1): 86-106.

Cook, Philip J. 1986. "The Demand and Supply of Criminal Opportunities." Crime and Justice 7 (1): 1-27.

2009. "Crime Control in the City: A Research-based Briefing on Public and Private Measures." Cityscape: A Journal of Policy Development and Research 11 (1): 53-79.

Cook, Philip J., and John H. Laub. 2002. "After the Epidemic: Recent Trends in Youth Violence in the United States." In Crime and Justice: A Review of Research, edited by Michael Tonry, 117-53. Chicago: University of Chicago Press.

Cook, Philip J., and Jens Ludwig. 2003. "The Effects of Gun Prevalence on Burglary: Deterrence vs. Inducement.” In Evaluating Gun Policy, edited by Jens Ludwig and Philip J. Cook, 74-118. Washington, DC: Brookings Institution Press.

. 2006. "The Social Costs of Gun Ownership." Journal of Public Economics 90 (1-2): 379-91.

Cook, Philip J., and John MacDonald. Forthcoming. "Public Safety through Private Action: An Economic Assessment of BIDs." The Economic Journal.

Copes, Heith, and Michael Cherbonneau. 2006. "The Key to Auto Theft: Emerging Methods of Auto Theft from the Offenders' Perspective." British Journal of Criminology 46 (5): 917-34.

Corby, Elizabeth A., John M. Roll, David M. Ledgerwood, and Charles R. Schuster. 2000. "Contingency Management Interventions for Treating the Substance Abuse of Adolescents: A Feasibility Study." Experimental and Clinical Psycholpharmacology 8 (3): 371-76.

Cornish, Derek, and Ronald V. Clarke. 2003. "Opportunities, Precipitators, and Criminal Decisions: A Reply to Wortley's Critique of Situational Crime Prevention" In Theory for Practice in Situational Crime Prevention, edited by Martha J. Smith and Derek B. Cornish, 41-96. Monsey, NY: Criminal Justice Press.

Cunningham, William C., John J. Strauchs, and Clifford W. Van Meter. 1990. Private Security Trends 1970 to 2000: The Hallcrest Report II. Boston: ButterworthHeinemann.

Draca, Mirko, Stephen Machin, and Robert Witt. 2010. "Crime Displacement and Police Interventions: Evidence from London's 'Operation Theseus." 'In The Eco- 
nomics of Crime: Lessons for and from Latin America, edited by Rafael Di Tella, Sebastian Edwards, and Ernesto Schargrodsky, 359-74. Chicago: University of Chicago Press.

Eck, John E. 2006. "Preventing Crime at Places." In Evidence-Based Crime Prevention, revised edition, edited by Lawrence W. Sherman, David P. Farrington, Brandon C. Welsh, and Doris Layton MacKenzie, 241-94. New York: Routledge.

Ehrlich, Isaac. 1974. "Participation in Illegitimate Activities: An Economic Analysis." In Essays in the Economics of Crime and Punishment, edited by Gary S. Becker and William M. Landes, 68-134. New York: National Bureau of Economic Research.

1981. "On the Usefulness of Controlling Individuals: An Economic Analysis of Rehabilitation, Incapacitation and Deterrence. American Economic Review 71 (3): 307-22.

1996. "Crime, Punishment, and the Market for Offenses." Journal of Economic Perspectives 10 (1): 43-67.

Ehrlich, Isaac, and Gary S. Becker. 1972. "Market Insurance, Self-Insurance, and Self-Protection.” Journal of Political Economy 80 (4): 623-48.

Forst, Brian. 1999. "Policing with Legitimacy, Efficiency, and Equity." In The Privatization of Policing: Two Views, edited by Brian Forst and Peter Manning, 1-48. Washington, DC: Georgetown University Press.

Friedman, Aaron, Aaron Naparstek, and Mateo Taussig-Rubbo. 2003. "Alarmingly Useless: The Case for Banning Car Alarms in New York City." Transportation Alternatives. http://www.transalt.org.

Gonzalez-Navarro, Marco. 2008. "Deterrence and Displacement in Auto Theft." Working Paper. Princeton University, October 15.

Gottfredson, Michael R., and Don M. Gottfredson. 1988. Decision Making in Criminal Justice: Toward the Rational Exercise of Discretion, 2nd edition. New York: Plenum.

Guerette, Rob T., and Kate J. Bowers. 2009. "Assessing the Extent of Crime Displacement and Diffusion of Benefits: A Review of Situational Crime Prevention Evaluations." Criminology 47 (4): 1331-68.

Harcourt, Bernard E. 2005. "Policing L.A.'s Skid Row: Crime and Real Estate Development in Downtown Los Angeles (An Experiment in Real Time)." University of Chicago Legal Forum May: 325-404.

Helperin, Joanne. 2009. "Evaluating Stolen Vehicle Recovery Systems: The Pros, Cons and Pricing." Edmunds, Inc. Posted November 20, 2009. www.edmunds .com/ownership/articles/128786/article.html.

Holter, Darryl. 2002. Four: The "Business Improvement Districts" Revolution. California Policy Options Paper 943, January 1. Los Angeles, CA: UCLA School of Public Affairs. Accessed January 2, 2009. http://repositories.cdlib.org/uclaspa/ cpo/943.

Houstoun, Lawrence O. 1997. BIDs: Business Improvement Districts. Washington, DC: Urban Land Institute in cooperation with the International Downtown Association.

Joyce, Theodore. 2004. "Did Legalized Abortion Lower Crime?" Journal of Human Resources 39 (1): 1-28.

Kindermann, Charles, James P. Lynch, and David Cantor. 1997. The Effects of the Re-design on Victimization Estimates. Washington, DC: Bureau of Justice Statistics.

Kruttschnitt, Candace, and Kristin Carbone-Lopez. 2009. "Customer Satisfaction: Crime Victims' Willingness to Call the Police." Research Paper. Washington, DC: The Police Foundation. 
Leinwand, Donna. 2009. "Car Theft Slows to Lowest in 20 Years." USA Today. Accessed February 18, 2011. http://www.usatoday.com/NEWS/USAedition/2009 -10-19-1Aautotheft19_ST_U.htm.

Levitt, Steven D. 1998. "The Relationship between Crime Reporting and Police: Implications for the Use of Uniform Crime Reports." Journal of Quantitative Criminology 14 (1): 61-81.

2004. "Understanding Why Crime Fell in the 1990s: Four Factors That Explain the Decline and Six That Do Not." Journal of Economic Perspectives 18 (1): 163-90.

Ludwig, Jens, and Philip J. Cook. 2001. "The Benefits of Reducing Gun Violence: Evidence from Contingent-Valuation Survey Data." Journal of Risk and Uncertainty 22 (3): 207-26.

MacDonald, John, Ricky Bluthenthal, Aaron Kofner, Robert Stokes, Amber Sehgal, Terry Fain, and Leo Beletsky. 2009. Neighborhood Effects on Crime and Youth Violence: The Role of Business Improvement Districts in Los Angeles. Santa Monica, CA: RAND Corporation.

MacDonald, John, and Robert J. Stokes. 2006. "Cities Should Enlist Business in Their Battle Against Crime.” Commentary. Santa Monica, CA: RAND Corporation. http://www.rand.org/commentary/2006/07/03/LABJ.html.

Miller, Ted R., Mark A. Cohen, and Shelli B. Rossman. 1993. "Victim Costs of Violent Crime and Resulting Injuries." Health Affairs 12 (4): 186-97.

Mitchell, Jerry. 2001. "Business Improvement Districts and the 'New' Revitalization of Downtown." Economic Development Quarterly 15 (2): 115-23.

2008. Business Improvement Districts and the Shape of American Cities. Albany: SUNY Press.

National Highway Transportation Safety Administration. 1998. "Auto Theft and Recovery: Effects of the Anti Car Theft Act of 1992 and the Motor Vehicle Theft Law Enforcement Act of 1984: Report to the Congress." NHTSA Report Number DOT HS 808 761. Accessed November 22, 2009. http://www.nhtsa.dot.gov/cars/ rules/regrev/evaluate/808761.html.

Philipson, Tomas J., and Richard A. Posner. 1996. "The Economic Epidemiology of Crime." Journal of Law and Economics 39 (2): 405-33.

Reiss, Albert J. 1971. The Police and the Public. New Haven, CT: Yale University Press.

Roman, Jonathan K. 2009. "What is the Price of Crime? New Estimates of the Cost of Criminal Victimization.” PhD diss., University of Maryland. http://www.lib .umd.edu/drum/handle/1903/9868.

Rosenmerkel, Sean, and Matthew Durose. 2009. "National Judicial Reporting Program Felony Sentences in State Courts, 2006.” NCJ 226846, December. Table 1.5.

Shavell, Steven. 1991. "Individual Precautions to Prevent Theft: Private versus Socially Optimal Behavior." International Review of Law and Economics 11 (2): 123-32.

Sklansky, David A. 2008. Democracy and Police. Stanford, CA: Stanford University Press.

Skogan, Wesley, and Kathleen Frydl, editors. 2004. Fairness and Effectiveness in Policing. Washington, DC: National Academy Press.

Stokes, Robert J. 2006. "Business Improvement Districts and Inner City Revitalization: The Case of Philadelphia's Frankford Special Services District." International Journal of Public Administration 29 (1-3): 173-86.

Tobolowsky, Peggy M. 2001. Crime Victim Rights and Remedies. Durham, NC: Carolina Academic Press.

Tremblay, Pierre, Yvan Clermont, and Maurice Cusson. 1994. "Jockeys and Joyrid- 
ers: Changing Patterns in Car Theft Opportunity Structures." British Journal of Criminology 34 (3): 307-21.

Turner, Susan, Terry Fain, John MacDonald, Amber Sehgal, with Jitahadi Imara, Felicia Cotton, Davida Davies, and Apryl Harris. 2007. Los Angeles County Juvenile Justice Crime Prevention Act: Fiscal Year 2004-2005 Report. Santa Monica, CA: RAND Corporation.

Tyler, Tom R., and Jeffrey Fagan. 2008. "Legitimacy and Cooperation: Why Do People Help the Police Fight Crime in their Communities?" Ohio State Journal of Criminal Law 6 (1): 231-75.

Webb, Barry. 1994. "Steering Column Locks and Motor Vehicle Theft: Evaluations from Three Countries." London: Home Office Police Research Group.

Welsh, Brandon C., and David P. Farrington. 2009. Making Public Places Safer: Surveillance and Crime Prevention. New York: Oxford University Press.

Zimring, Franklin E. 2007. The Great American Crime Decline. New York: Oxford University Press. 